\title{
Efficiency of Various Nutritional Sources to Improve Physical Properties of Saline-Sodic Soil
}

\author{
Noor-us-Sabah, Ghulam Sarwar, Muhammad Ibrahim ${ }^{1 *}$, Mukkram Ali Tahir, Yasir Iftikhar, \\ Muhammad Sajjad Haider, Kyung-Hwa Han ${ }^{2}$, Sang-Keun $\mathrm{Ha}^{2}$, and Yong-Seon Zhang
}

\author{
University College of Agriculture, University of Sargodha, Sargodha (40100), Pakistan \\ ${ }^{1}$ Department of Environmental Sciences, Government College University, Faisalabad (38000), Pakistan \\ ${ }^{2}$ Department of Agricultural Environment, National Academy of Agricultural Science, Rural Development \\ Administration (RDA), Suwon (441-707), Republic of Korea
}

This study was conducted to evaluate the efficiency of various inorganic and organic materials to improve physical properties of soil. Saline sodic soil (saturation percentage $=40.36 \%, \mathrm{EC}_{\mathrm{e}}=5.15 \mathrm{dS} \mathrm{m}^{-1}, \mathrm{pH}_{\mathrm{s}}=8.70$, $\mathrm{SAR}=18.84\left(\mathrm{~m} \mathrm{~mol} \mathrm{~L}^{-1}\right)^{1 / 2}$, bulk density $\left.=1.49 \mathrm{Mg} \mathrm{m}^{-3}\right)$ was collected, brought to wire house and filled in pots after laboratory analysis for various parameters. Different sources of organic nutrients like farm manure (FM), press mud, compost, poultry manure and sesbania green manure were analyzed for their chemical composition. The experiment comprised of 12 treatments replicated thrice; $T_{1}$ : control (recommended NPK), $T_{2}: 1 / 2$ recommended $N P K, T_{3}:$ FM at $1.5 \%$ by soil weight, $T_{4}$ : pressmud at $1.5 \%$ by soil weight, $T_{5}:$ compost at $1.5 \%$ by soil weight, $T_{6}$ : poultry manure at $1.5 \%$ by soil weight, $T_{7}$ : sesbania green manure at $1.5 \%$ by soil weight, $T_{8}: T_{2}+F M$ at $0.75 \%$ by soil weight, $T_{9}: T_{2}+$ pressmud at $0.75 \%$ by soil weight, $T_{10}: T_{2}+$ compost at $0.75 \%$ by soil weight, $T_{11}: T_{2}+$ poultry manure at $0.75 \%$ by soil weight, $T_{12}: T_{2}+$ sesbania green manure at $0.75 \%$ by soil weight. These treatments were applied using completely randomized (CR) design and appropriate time was given to decompose these organic nutritional sources. Seeds of wheat cultivar Sahar-2006 were sown. After harvesting the wheat, soil samples were collected from each pot and analyzed for various physical properties like bulk density, porosity and saturation percentage. An improvement in physical properties (bulk density, porosity and saturation percentage) of soil was noticed with the application of various organic nutritional sources but role of compost alone $\left(T_{5}\right)$ remained prominent.

Key words: Saline-sodic soil, Physical properties, Saturation percentage, Bulk density, Percent pore space

\section{Introduction}

Land is one of the major non-renewable assets that is posing serious hazard of degradation. Occurrences of degraded soils are common in the world. In Pakistan salinity is threatening about 6.67 million hectares area in irrigated belt. Efforts are being made to utilize these soils for sustainable agriculture since independence. Soils of Pakistan are alkaline and calcareous in nature. There are several constraints for it including low organic matter, alkaline soil $\mathrm{pH}$, calcareousness and deteriorated physical properties. Soils are also being

Received : January 18. 2012 Accepted : February 3. 2012

*Corresponding author : Phone: +92419201566

E-mail: ebrahem.m@gmail.com, ghulamsarwar@uos.edu.pk depleted due to harmful use of plant nutrients and cropping sequences. Hence, restoration of physical properties of soil is important, for which the addition of organic materials in addition to other field practices is essential (Anonymous, 1998).

During last few decades, the fertilizer use has been increased significantly in Pakistan. But there are several hurdles for the application of fertilizer at recommended rate and in balance proportion by low income farmers. Organic nutritional sources can be economical fertilizer and a valuable source of plant nutrients. In Pakistan, several organic nutritional sources like FM, green manures, straws and crop residues are available. However, the shortage of these products and the use of straw as animal feed and burning of crop residues limited the scope for their use as organic supplement 
to increase soil organic matter for sustaining crop yield (Ibrahim et al., 2008; Ibrahim et al., 2011).

The addition of organic materials either in the form of manures or crop residues has beneficial effects on the physical properties of soils (Sarwar et al., 2008; Bationo and Mokwunye, 1991). Soil amendment with manures, municipal bio solids, and other organic wastes has been found to improve the physical properties of soil. Beneficial effects of organic soil amendments include decreased soil bulk density and increased water holding capacity, aggregate stability, saturated hydraulic conductivity, water infiltration rate and biochemical activity (Iqbal et al., 2008). Application of organic materials like FM to the soil not only supplies plant nutrients but also improves the physical properties of soil such as structure, porosity and water retention capacity, which helps in root penetration (Zhu and Yao, 1993). The application of organic material helps the microorganisms to produce polysaccharides, which improve the soil structure (Guar, 1994). Agbede et al. (2008) investigated the effect of poultry manure on soil physical and concluded that the poultry manure significantly reduced soil bulk density and temperature and increased the porosity and moisture content. Adeleye et al. (2010) studied the effect of poultry manure on soil physical properties and concluded that poultry manure application ensure stability of soil structure; it reduced soil bulk density, temperature and also increased total porosity and soil moisture retention capacity. The present studies were, however planned to compare the efficiency of various nutritional sources (amendments) for improving soil physical properties.

\section{Materials and Methods}

A pot experiment was conducted at University College of Agriculture, University of Sargodha, Sargodha, during the year 2009, to study the effect of various organic and inorganic nutritional sources on physical properties of saline-sodic soil. During a detailed soil survey for the selection of saline-sodic soil, soil samples were collected from various places and analysed in the laboratory. Soil of the desired level (saturation percentage $=40.36 \%$, $\mathrm{EC}_{\mathrm{e}}=5.15 \mathrm{dS} \mathrm{m}^{-1}, \mathrm{pH}_{\mathrm{s}}=8.70, \mathrm{SAR}=18.84(\mathrm{~m} \mathrm{~mol}$ $\left.\mathrm{L}^{-1}\right)^{1 / 2}$, bulk density $=1.49 \mathrm{Mg} \mathrm{m}^{-3}$ ) was selected and collected in bulk volume. The collected soil was shifted to sample room, air dried, ground, sieved and filled at $7 \mathrm{~kg}$ per pot. The experiment comprised of 12 treatments replicated thrice as detailed below;

$$
\begin{aligned}
& \mathrm{T}_{1}=\text { Control (recommended NPK) } \\
& \mathrm{T}_{2}=1 / 2 \text { recommended NPK } \\
& \mathrm{T}_{3}=\text { Farm manure }(\mathrm{FM}) \text { at } 1.5 \% \text { by soil weight } \\
& \mathrm{T}_{4}=\text { Pressmud at } 1.5 \% \text { by soil weight } \\
& \mathrm{T}_{5}=\text { Compost at } 1.5 \% \text { by soil weight } \\
& \mathrm{T}_{6}=\text { Poultry manure at } 1.5 \% \text { by soil weight } \\
& \mathrm{T}_{7}=\text { Sesbania green manure at } 1.5 \% \text { by soil weight } \\
& \mathrm{T}_{8}=\mathrm{T}_{2}+\text { FM at } 0.75 \% \text { by soil weight } \\
& \mathrm{T}_{9}=\mathrm{T}_{2}+\text { pressmud at } 0.75 \% \text { by soil weight } \\
& \mathrm{T}_{10}=\mathrm{T}_{2}+\text { compost at } 0.75 \% \text { by soil weight } \\
& \mathrm{T}_{11}=\mathrm{T}_{2}+\text { poultry manure at } 0.75 \% \text { by soil weight } \\
& \mathrm{T}_{12}=\mathrm{T}_{2}+\text { sesbania green manure at } 0.75 \% \text { by soil } \\
& \text { weight. }
\end{aligned}
$$

These treatments were tri-replicated under completely randomized statistical arrangements and appropriate time was given to decompose these organic nutritional sources. Seeds of wheat cultivar Sehar-2006 were sown. After harvesting the crop, soil samples from each pot were collected, air dried and passed through $2 \mathrm{~mm}$ sieve. Laboratory work was carried out by following the analytical methods of U.S. Salinity Laboratory Staff (1954). All the calculations were made on oven dried soil weight basis. All collected data were analyzed statistically using $\mathrm{R}$ software.

\section{Results}

Saturation percentage Saturation percentage of soil is affected by many properties; some of which may be chemical and the others of physical nature. It was depicted from the data that maximum value of saturation percentage $(41 \%)$ was recorded in $T_{2}(1 / 2$ recommended NPK) while minimum value of saturation percentage (35\%) was observed in $\mathrm{T}_{5}$ (compost at $1.5 \%$ by soil weight). Differences among various treatments regarding saturation percentage were significant statistically (Fig. 1). However, treatments $T_{3}, T_{4}, T_{6}, T_{7}, T_{8}, T_{9}$ and $T_{11}$ remained at par with values of $38,38.33,38,38.67$, 39 and 39, respectively, when adjudged statistically. Similar behavior of non-significance was showed by $T_{1}, T_{10}$ and $T_{12}$ recorded values of $39.67,39.33$ and 39.33 respectively, for each other. The minimum saturation percentage was determined when compost was applied at $1.5 \%$ by soil weight $\left(\mathrm{T}_{10}\right)$.

Bulk density Bulk density is an important physical 


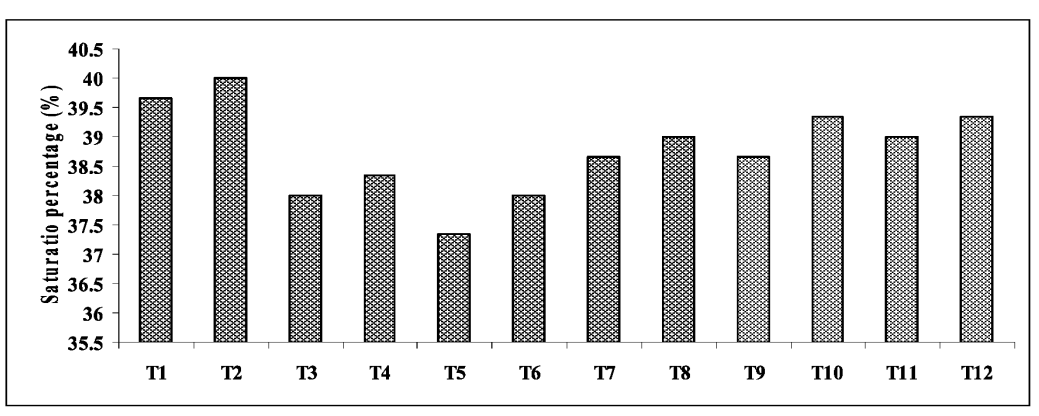

Fig. 1. Effect of various nutritional sources on saturation percentage of saline-sodic soil.

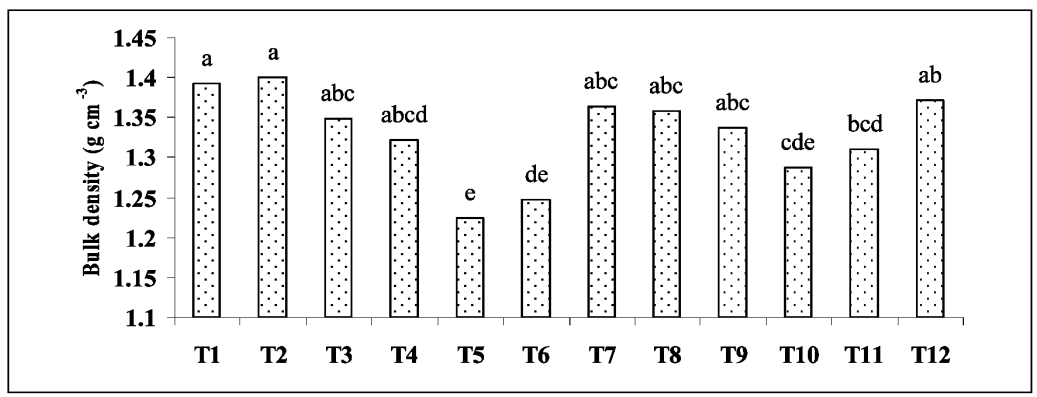

Fig. 2. Effect of various nutritional sources on bulk density of saline-sodic soil.

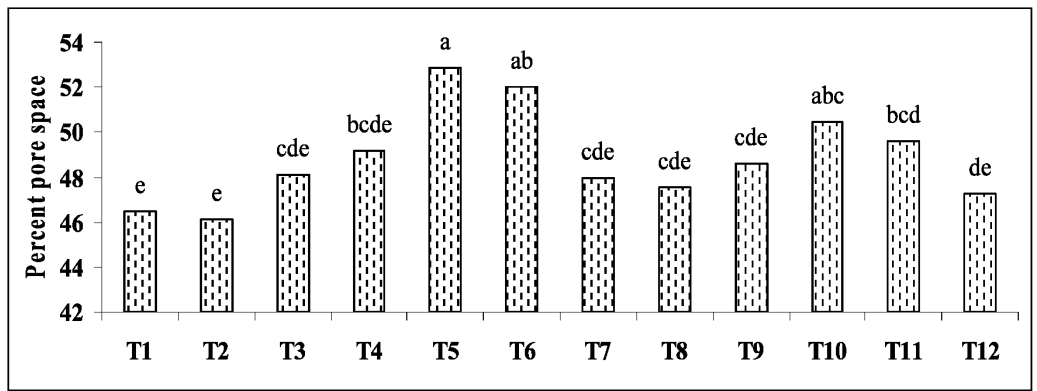

Fig. 3. Effect of various nutritional sources on percent pore space of saline-sodic soil.

property which expresses the ratio between undisturbed volume and mass of soil. The lesser values indicate the ease of water and air passage while more numerical values reveal decreased permeability to air and water (Tagar and Bhatti, 2001). It is evident from the data that application of organic nutritional sources, either alone or in combination with chemical fertilizers, caused significant reduction in bulk density. Differences among various treatments for bulk density were found significant statistically (Fig. 2). Data revealed that $T_{5}$ (compost at $1.5 \%$ by soil weight) significantly reduced the bulk density showing value of $1.225 \mathrm{Mg} \mathrm{m}^{-3}$. This value was the lowest when compared with other treatments. Whereas, maximum bulk density was recorded in $T_{2}$ ( $1 / 2$ recommended NPK) followed by $T_{1}$ (full recommended NPK) showing value of 1.4 and $1.392 \mathrm{Mg}$ $\mathrm{m}^{-3}$, respectively. Both these treatments $\mathrm{T}_{3}$ (FM at
$1.5 \%$ by soil weight) and $\mathrm{T}_{4}$ (pressmud at $1.5 \%$ by soil weight) were also non-significant for each other with values of 1.349 and $1.322 \mathrm{Mg} \mathrm{m}^{-3}$ respectively. Similarly treatments $\mathrm{T}_{7}$ (sesbania at $1.5 \%$ by soil weight), $\mathrm{T}_{8}$ (FM at $0.75 \%$ by soil weight $+1 / 2$ recommended NPK) and $T_{9}$ (pressmud at $0.75 \%$ by soil weight $+1 / 2$ recommended NPK), also remained at par when adjudged statistically possessing numerical values of $1.363,1.359$ and $1.337 \mathrm{Mg} \mathrm{m}^{-3}$, respectively. Thus, application of compost either alone $\left(T_{5}\right)$ or in combination with chemical fertilizers $\left(\mathrm{T}_{10}\right)$ proved superior in reducing bulk density as compared to FM, pressmud, poultry manure and sesbania in their sole or combined addition.

Percent pore space It is the derived property expressing the percent of the pore space involving the bulk density and particle density figures. It is that proportion of a 
soil volume which is occupied by air and water. For an ideal soil, half of pore spaces must be filled with water and half with air (Tagar and Bhatti, 2001). Pore spaces gradually increase with the application of organic nutritional sources. It $\mathrm{s}$ value was the highest in $\mathrm{T}_{5}$ (compost at $1.5 \%$ by soil weight) showing value of $52.89 \%$ while it was the lowest in $\mathrm{T}_{2}(1 / 2$ recommended NPK) with numerical value of $46.15 \%$ (Fig. 3). It was noted that differences among various treatments were significant in terms of statistics. Data revealed that $\mathrm{T}_{1}$ (control) and $\mathrm{T}_{2}(1 / 2$ recommended NPK) remained at par statistically. Treatments $\mathrm{T}_{3}$ (FM at $1.5 \%$ by soil weight) was followed by $\mathrm{T}_{7}$ (sesbania at $1.5 \%$ by soil weight) and $\mathrm{T}_{8}$ (FM at $0.75 \%$ by soil weight + $1 / 2$ recommended NPK) showing value of $48.13,47.98$ and $47.56 \%$, respectively and differences among these treatments were non-significant when noted statistically. It is evident from the data that application of compost either alone $\left(\mathrm{T}_{5}\right)$ or in combination with chemical fertilizers $\left(\mathrm{T}_{10}\right)$ proved superior in improving pore space. However, other organic nutritional sources like FM, pressmud, poultry manure and sesbania either alone or in integration with chemical fertilizers proved superior to the application of chemical fertilizers $\left(T_{1}\right.$ and $\left.T_{2}\right)$.

\section{Discussion}

Soil physical properties influence how soils function in an ecosystem and how soils can best be managed. Success or failure of both agricultural and engineering projects often hinges on the physical properties of the soil used. Occurrence and growth of many plant species are closely related to soil physical properties. Hence, knowledge of the basic soil physical properties is not only of great practical value but also helpful in understanding many aspects in soils. Because physical properties exert a marked influence on behaviour of soils with regard to plant growth, hydrology, environmental management and engineering use (Brady and Weil, 2005).

Saturation percentage is the water content of a saturated soil paste expressed on oven-dry weight basis whereas, degree of saturation is value of pores occupied by water. Complete saturation is seldom attained due to entrapped air. Saturation percentage is very important physical property which is dependent upon many other properties some of which may be chemical and other of physical nature. Other factors remaining constant, a change in the total soluble salts or the exchangeable sodium affects soil saturation percentage. At the same time the rate of soil organic matter can never be ignored while describing this important soil property. Addition of organic matter in the form of FM, pressmud, poultry manure and sesbania green manure when applied alone and in combination with chemical fertilizer affects the saturation percentage of soil significantly (Fig. 1). Addition of organic matter enhanced water holding capacity of soil, which consequently increased saturation percentage of soil.

Bulk density is an important physical property which expresses the ratio between undisturbed volume and mass of soil. The lesser values indicate the ease of water and air passage while more numerical values reveal decreased permeability to air and water. The dry bulk density of a soil gives an indication of the soil's strength and thus the resistance offered to the crop roots as these penetrate the soil. It depends on both particle density and pore space. It was noticed that bulk density of saline-sodic soil decreased significantly in all experimental treatments (Fig. 2). The possible reason for lowering the bulk density value is the addition of organic matter in either form in the soil. As addition of organic matter increases the porosity of soil, permeability of water and air, consequently value of bulk density decreased (Ibrahim et al., 2010). Bulk density of soil depends upon soil texture, structure, drainage, clay type, clay content and organic matter percentage (Brady \& Weil, 2005). Hence, up gradation of organic matter percentage lowered the bulk density value. The addition of organic matter improved the impaired physical properties, ease the leaching of salts especially sodium. In this way, reduction in $\mathrm{pH}$ and SAR value occurs when divalent cations $\left(\mathrm{Ca}^{2+}\right)$ replaces the exchangeable sodium and resultantly excessive quantities of salts including sodium leave the soil solution through leaching (Sarwar et al., 2008). This whole process was led through the addition of organic matter in the soil with net decrease in bulk density value (Tagar and Bhatti, 2001).

The per cent pore space is derived physical property which expresses the volume of total pore in the soil. Values of percent pore space are inversely linked with bulk density. It means a decrease in bulk density values will raise the value of percent pore space and vice 
versa (Fig. 3). Hence, this change in percent pore space values is bulk density dependent, which is based on status of soil organic matter. These results are in line with Khan et al. (2006) and Sinha et al. (1997). According to Adesodun et al. (2005) application of poultry manure to soil increased soil organic matter and aggregate stability. The improvement in soil physical properties is attributed to the improvement in soil organic matter content, which resulted in decreased bulk density (Iqbal et al., 2008; Sarwar et al., 2010). These finding are in accordance with Ewulo et al. (2008), Adeleye et al. (2010), Agbede et al. (2008), Elsharawy et al. (2008), Sultani et al. (2007), Pagliai et al. (2004) and Sarwar et al. (2011).

\section{References}

Adeleye, E.O., L.S. Ayeni and S.O. Ojeniyi. 2010. Effect of poultry manure on soil physic-chemical properties, leaf nutrient contents and yield of Yam (Dioscorea rotundata) on Alfisol in Southwestern Nigeria. J. Amer. Sci. 6:871-878.

Adesodun, J.K., J.S. Mbagwu and N. Oti. 2005. Distribution of carbon, nitrogen and phosphorus in water stable aggregates of an organic waste amended Ultisol in southern Nigeria. Bioresour. Technol. 96:509-516.

Agbede, T.M., S.O. Ojeniyi and A.J. Adeyemo. 2008. Effect of poultry manure on soil physical and chemical properties, growth and grain yield of sorghum in South West Nigeria. Amer-Euras. J. Sustain. Agric. 2:72-77.

Anonymous. 1998. Micronutrient in Agriculture, Paksitan perspective, NFDC, Islamabad, Pakistan.

Bationo, A. and A.U. Mokwunye. 1991. Role of manures and crop residue in alleviating soil fertility constraints to crop production: With special reference to the Sahelian and Sudanian zones of West Africa. Nutr. Cycl. Agroecosys. 29: 117-125.

Brady, N.C. and R.R. Weil. 2005. The nature and properties of soils. $13^{\text {th }}$ Edition. Pearson Education, Inc. and Dorling Kindersley Publishing Inc. pp. 137-192.

Elsharawy, M.A.O., M.M. Elbordiny and S.A. Abdelwaheed. 2008. Improvement of a salt affected soil on Bahr El-Bakar areas using certain industrial by-products: 1 . Effects on physical and chemical characteristics. J. App. Sci. Res. 4(7):839-846.

Ewulo, B.S., S.O. Ojeniyi and D.A. Akanni. 2008. Effect of poultry manure on selected soil physical and chemical properties, growth, yield and nutrient status of tomato. African J. Agric. Res. 3:612-616.

Guar, A.C. 1994. Bulky organic manures and crop residues. In: Tandon, H.L.S. (ed.), Fertilizers, Organic Manures, Recyclable Wastes and bio-fertilizers, pp. 36-51. Fertilizers Development and Consultation Organization, New Delhi, India.

Ibrahim, M., A. Hassan, M. Iqbal and E.E. Valeem. 2008. Response of wheat growth and yield to various levels of compost and organic manure. Pak. J. Bot. 40:2135-2141.

Ibrahim, M., A. Hassan, M. Arshad and A. Tanveer. 2010. Variation in root growth and nutrient element of wheat and rice: effect of rate and type of organic materials. Soil Environ. 29:47-52.

Ibrahim, M., M. Yamin, G. Sarwar, A. Anayat, F. Habib, S. Ullah and S. Rehman. 2011. Tillage and farm manure affect root growth and nutrient uptake of wheat and rice under semi-arid conditions of Pakistan. Appl. Geochem. 26:S194S197.

Iqbal, M., A. Hassan and M. Ibrahim. 2008. Effects of tillage systems and mulch on soil physical quality parameters and maize (Zea mays L.) yield in semi-arid Pakistan. Biol. Agric. Hort. 25:311-325.

Khan, M.A., N. Jan, Q. Sultana, S.R. Ahmad and A. Rahman. 2006. Effect of different organic materials and chemical fertilizers on the yield of wheat and physical properties of soil. Sarhad J. Agric. 22:437-441.

Pagliai, M., N. Vignozzi and S. Pellegrini. (2004). Soil structure and the effect of management practices. Soil Till. Res. 79: 131-143.

Sarwar. G., H. Schmeisky, N. Hussain, S. Muhammad, M. Ibrahim and E. Safdar. 2008. Improvement of soil physical and chemical properties with compost application in rice-wheat cropping system. Pak. J. Bot. 40:275-282.

Sarwar, M.A., M. Ibrahim, M. Tahir, K. Ahmad, Z.I. Khan and E.E. Valeem. 2010. Appraisal of pressmud and inorganic fertilizers on soil properties, yield and sugarcane quality. Pak. J. Bot. 42:1361-67.

Sarwar, G., M. Ibrahim, M.A. Tahir, Y. Iftikhar, M.S. Haider, N. Sabah, K.H. Han, S.G. Ha and Y.S. Zhang. 2011. Effect of compost and gypsum application on the chemical properties and fertility status of saline-sodic soil. Korean J. Soil Sci. Fert. 44:510-516.

Sinha, S. K., V.N. Singh and K.P. Singh. 1997. Effect of combined use of fertilizers on physical and chemical properties of an alluvial soil. J. Res. 9, 31-34.

Sultani, M.I., M.A. Gill, M.M. Anwar and M. Athar. 2007. Evaluation of soil physical properties as influenced by various green manuring legumes and phosphorus fertilization under rain fed conditions. Intl. J. Environ. Sci. Technol. 4:109-118.

Tagar, S. and A. Bhatti, 2001. Physical Properties of Soil. In: Soil Science. (2nd ed.), pp. 130-40. National Book Foundation, Islamabad.

U.S. Salinity Laboratory Staff. 1954. Diagnosis and Improvements of saline and alkali soils. Handbook No. 60. USDA. U.S. Govt. Printing Office, Washington, DC, USA.

Zhu, H.X. and X.L. Yao. 1993. The physical effect of organic material on rice-based cropping system. Acta Pedologica Sinica. 30:137-145. 